\title{
Effect of copper (II) ions on morpho-physiological and biochemical variables in Colobanthus quitensis
}

\author{
Marely Cuba-Díaz ${ }^{1 *}$, Camilo Marín ${ }^{1,2}$, Kriss Castel $^{1,2}$, Ángela Machuca² ${ }^{2}$ Sergio Rifo ${ }^{3}$.
}

${ }^{1}$ Laboratory of Biotechnology and Environmental Studies, Department of Plant Science and Technology, School of Science and Technology. University of Concepción, Los Ángeles Campus. Juan Antonio Coloma 0201, Los Ángeles, Chile. ${ }^{2}$ Laboratory of Biochemistry and Biotechnology. Department of Plant Science and Technology, School of Science and Technology. University of Concepción, Los Ángeles Campus. Juan Antonio Coloma 0201, Los Ángeles, Chile. ${ }^{3}$ Department of Business Management. School of Science and Technology. University of Concepción, Los Ángeles Campus. Juan Antonio Coloma 0201, Los Ángeles, Chile. *Corresponding autor: mcuba@udec.cl

\begin{abstract}
Colobanthus quitensis is a species with a wide geographical distribution, including Antarctica. This species must endure a series of limiting abiotic factors in its habitats, such as, high metal ion concentrations. It has been described to inhabit areas where only metal-tolerant species can live. Therefore, it is postulated that the study of this species may provide information about copper tolerance mechanisms. We evaluated the effect of copper (II) ions (control, 100 and $500 \mu \mathrm{M}$ ) on C. quitensis seedlings in vitro, determining morpho-physiological and biochemical variables. Copper showed a significantly negative effect on the development of new shoots (500 $\mu \mathrm{M})$ and floral apex appearance $(100 \mu \mathrm{M})$. The analyzed $\mathrm{Cu}$ concentrations significantly affected leaf and root length and induced a significant increase in guaiacol peroxidase (G-POD) enzyme activity. The highest proline accumulation took place in seedlings subjected to $500 \mu \mathrm{M}$. Furthermore, this concentration induced a significant reduction in chlorophyll a content and exhibited oxidative stress evaluated through an increase in malondialdehyde levels. This is the first study to demonstrate evidence of copper effects on morphological, physiological and biochemical variables in C. quitensis.
\end{abstract}

Keywords: Antarctica, in vitro, oxidative stress, proline, tolerance mechanisms 


\section{Introduction}

Metals and metalloids enter the ecosystem due to both anthropogenic and natural processes. High contents of trace elements have been found in many soils, which may become toxic for plants and other components of terrestrial biota (Violante et al., 2010). In Central Chile, environmental problems of metal contamination due to mining activity have required various studies in order to determine the toxicity threshold to plants in soils exposed to copper mining activities (Verdejo et al., 2016). Copper (Cu) has been considered to be an essential micronutrient for plants; it is an element of vital importance in seed production, disease resistance, and regulation of water catchment (Wuana and Okieimen, 2011) and of other essential nutrients, which largely depend on copper solubility in the soil and the type of soil (Joshi et al., 2015). Essential micronutrients are required in low concentrations, so that the plant can develop normally, but are toxic in high concentrations (Wuana and Okieimen, 2011). These can lead to biochemical alterations, which are widely documented (e.g. Sharma et al., 2012; Sreekanth et al., 2013). Cu interferes in several physiological processes and therefore, potentially inhibits plant growth, resulting in a decrease in performance, delays in leaf and root growth, as well as anatomical and ultrastructural alterations that often lead to the formation and accumulation of reactive oxygen species (ROS) (Dey et al., 2014).

Some plant species can withstand the excess of metals present in the environment whether through compartmentalization (Dal corso et al., 2013), chelation, exclusion or accumulation (Thounaojam et al., 2012). This capability is typically described in particular in species that grow or show a frequency and/or high abundance in copper-contaminated soils, allowing soil stabilization through uptake and retaining metals. It has been suggested that this specific compartmentalization of metals in the cell may be the reason for a plant's development of more complex tolerance mechanisms to certain metals (Dal corso et al., 2013).

Colobanthus quitensis Kunth. (Bartl.) Caryophyllaceae presents a wide distribution from Mexico, the Ecuadorian and Bolivian Andes to the south of Peru, and throughout the Argentinean and Chilean Andes to Western Patagonia. Moreover, its distribution extends to the Falkland Islands, the sub-Antarctic, Antarctic islands (and the western coast of the Antarctic Peninsula to $68^{\circ} 42^{\prime}$ S on Tierra Firma (Moore, 1970; Lewis-Smith, 1993).

In general, the distribution of this species is dominated by a series of extreme abiotic factors such as: freezing temperatures (Lewis-Smith, 2003), strong winds, different states of water availability, the presence of metal ions in high concentrations, and low $\mathrm{pH}$ in soil (Androsiuk et al., 2015); many of these are considered to be limiting factors for the survival of plant species. The distribution of $C$. quitensis follows the pattern characterized by the presence of $\mathrm{Cu}$ throughout the Americas (Borsdorf et al., 2012) and Antarctica (Lu et al., 2012). Thus, it becomes clear that $C$. quitensis has developed tolerance mechanisms that would enable it to survive in the presence of high metal concentrations in the environment. Currently, there are no studies related to the tolerance of $C$. quitensis to $\mathrm{Cu}$; however, there are several other studies that have shown tolerance mechanisms to other extreme abiotic agents in its habitat (Bravo et al., 2007; Bascuñán-Godoy et al., 2012; Cuba-Díaz et al., 2017).

It is proposed that $C$. quitensis may deploy a series of morpho-physiological and biochemical strategies that allow it to mitigate the harmful effects of high $\mathrm{Cu}$ ion concentrations. To test this hypothesis, we propose evaluating the effect of the $\mathrm{Cu}$ (II) ions on the in vitro propagation ability of an Antarctic population of C. quitensis. 


\section{Materials and Methods}

\subsection{Plant material and treatments}

Leaf explants with a root fragment from previously established in vitro plantlets of an insular Antarctica population of C. quitensis were selected using a laminar flow chamber. 10 explants per flask were placed into Murashige and Skoog (MS) culture medium, supplemented with 3\% sucrose, IAA (indoleacetic acid) (0.25 mg L $\left.\mathrm{m}^{-1}\right)$, BAP (Benzylaminopurine) $(0.5 \mathrm{mg}$ $\left.\mathrm{L}^{-1}\right)$, STS (silver thiosulphate) $(10 \mu \mathrm{M})$. The $\mathrm{pH}(5.7 \pm$ 2) was adjusted and $0.7 \%$ agar was added (Cuba-Díaz et al., 2014). $\mathrm{CuSO}_{4} 5 \mathrm{H}_{2} \mathrm{O}$ was added to the media according to the applied treatments: control $(0 \mu \mathrm{M})$, minimum $(100 \mu \mathrm{M})$, and maximum $(500 \mu \mathrm{M})$. The $\mathrm{Cu}$ (II) ion concentrations were established according to a preliminary laboratory test (unpublished data). 20 flasks with 10 plants in each one were used for each treatment, for a total of 60 flasks. The culture flasks were brought to a growth chamber with a $16 / 8 \mathrm{~h}$ light/ darkness photoperiod at a temperature of $20 \pm 2^{\circ} \mathrm{C}$ and a light intensity of $50 \pm 5 \mu \mathrm{mol} \mathrm{m} \mathrm{m}^{-2} \mathrm{~s}^{-1}$ for 60 days.

\subsection{Morpho-physiological variables}

The total number of explants per flask was recorded at 30 and 60 days, exhibiting an increase in the development of new shoots and roots and in the appearance of floral apices and chlorosis; these two last variables are negative indicators of in vitro development (Cuba-Díaz et al., 2014). At the end of the assay (day 60), 20 seedlings were selected randomly. Their roots were carefully washed to eliminate traces of the culture medium. Each plant's roots were carefully dried with sterile paper towels, and the fresh weight $(\mathrm{FW})$ and leaf and root length were measured using a caliper (KAMASA $\AA$ ). Subsequently, the seedlings were dried in an oven at 37 $\pm 0.2{ }^{\circ} \mathrm{C}$ until constant weight, the moment in which the dry weight was recorded. The water content (WC) was determined based on the FW and DW, using the following formula (Cheng et al., 2012):

$$
\mathrm{WC}=\frac{(\mathrm{FW}-\mathrm{DW})}{\mathrm{FW}} \times 100
$$

FW - fresh weight and DW - dry weight.

Chlorophyll fluorescence (Fv/Fm) was measured in 5 leaves per plantlet, which were darkened for 30 min to maintain all reaction centers open and finally, a saturation pulse of $3500 \mu \mathrm{mol} \mathrm{m} \mathrm{m}^{-2} \mathrm{~s}^{-1}$ was applied using a portable fluorometer (Pocket PEA Hansatech).

\subsection{Proline content}

Proline content was determined according to Bates et al. (1973). At the end of the assay (60 days) for each treatment, $250 \mathrm{mg}$ of fresh aerial tissue (leaves and stems, and in triplicate) were taken that were pulverized in the presence of liquid nitrogen and homogenized with $1.25 \mathrm{ml}$ of $3 \%$ sulfosalicylic acid, followed by filtration into test tubes. The resulting solution was mixed with glacial acetic acid and ninhydrin reagent in a 1:1:1 proportion. Subsequently, each tube was agitated in vortex for a few seconds. Each covered tube was incubated for $1 \mathrm{~h}$ at $100{ }^{\circ} \mathrm{C}$ in a water bath. After this period, the reaction was stopped in an ice bath $1 \mathrm{ml}$ of toluene was added to the reaction, agitating in vortex for $30 \mathrm{~s}$. After precipitation of the toluene, the proline deposited in the supernatant was taken with a micropipette and its absorbance was measured in a UVVis spectrophotometer (Thermo scientific GENESYS 10UV) at $520 \mathrm{~nm}$ wavelength using quartz cuvettes. Proline content was expressed as $\mu \mathrm{g}$ of proline per mg of fresh plant material. 


\subsection{Photosynthetic pigment content}

Fresh leaf tissue (200 mg and in triplicate) was pulverized in the presence of liquid nitrogen and the pigments were extracted in $15 \mathrm{ml}$ of $80 \%$ acetone. The volume obtained was filtered into volumetric flasks, which were diluted with $80 \%$ acetone. The content was homogenized by agitation. The extracts were kept in plugged test tubes and covered with aluminum foil. The absorbance of each one of these was measured in spectrophotometer tubes at 470 (carotenoids), 646 (Chlorophyll a), and $663 \mathrm{~nm}$ (Chlorophyll b). The pigment content was expressed as $\mathrm{mg}$ of pigments per $g$ of fresh plant material (Steubing et al., 2002).

\subsection{Determination of lipid peroxidation}

The $200 \mathrm{mg}$ samples of fresh aerial tissue (in triplicate) were macerated in liquid nitrogen and homogenized with $1 \mathrm{ml}$ of $0.5 \%$ trichloroacetic acid (TCA). The homogenates were centrifuged at $5300 \mathrm{rpm}$ for $20 \mathrm{~min}$ at room temperature. The supernatant was taken and mixed with $1 \mathrm{ml}$ of $0.5 \%$ thiobarbituric acid (TBA) dissolved in 20\% TCA. The mixture was incubated at $96{ }^{\circ} \mathrm{C}$ for $30 \mathrm{~min}$ and cooled in an ice bath. Finally, the absorbance was measured at 532 and $600 \mathrm{~nm}$. Lipid peroxidation was expressed as nmol of malondialdehyde (MDA) per gram of fresh tissue (Dhindsa et al., 1981).

\subsection{Enzyme extract and catalase (CAT) and guaia- col peroxidase (G-POD) activities}

Enzyme extracts were prepared by pulverizing 100 $\mathrm{mg}$ of fresh aerial tissue (in triplicate) in the presence of liquid nitrogen; the obtained powder was homogenized in $1.5 \mathrm{ml}$ potassium phosphate buffer ( $\mathrm{pH}$ 7.4). Each homogenate was centrifuged at
$10000 \mathrm{~g}$ for $20 \mathrm{~min}$ at $4{ }^{\circ} \mathrm{C}$ and the supernatant was retrieved. To determine CAT activity, $1.78 \mathrm{ml}$ potassium phosphate buffer ( $\mathrm{pH} 7.5$ ), $100 \mu 1 \mathrm{H}_{2} \mathrm{O}_{2} 100 \mathrm{mM}$, and $120 \mu 1$ enzyme extract were mixed in a quartz cuvette. The mixture was homogenized by agitation 3 times and the absorbance was measured at $240 \mathrm{~nm}$ with intervals of $10 \mathrm{~s}$ for $30 \mathrm{~min}$. As a blank, the same reaction mixture was used, replacing the enzyme extract with an identical volume of deionized water. Enzyme activity was expressed as IU $\mathrm{min}^{-1}$ (Ulrich, 1974). G-POD activity was determined in a reaction carried out in a quartz cuvette, where $2.80 \mathrm{ml}$ potassium phosphate buffer ( $\mathrm{pH} 7.0), 50 \mu$ guaiacol 12 $\mathrm{mM}, 50 \mu \mathrm{H}_{2} \mathrm{O}_{2} 100 \mathrm{mM}$, and $100 \mu \mathrm{l}$ enzyme extract were added. The mixture was homogenized by agitation 3 times and the absorbance was measured at 470 $\mathrm{nm}$ wavelength with intervals of $10 \mathrm{~s}$ for $10 \mathrm{~min}$. As a blank, the same reaction mixture was used, replacing the enzyme extract with an identical volume of deionized water (Kireyko et al., 2006).

\subsection{Experimental design and statistical analysis}

All assays were randomized, using 20 replicas per treatment, considering an experimental unit of 10 seedlings per flask, where there were a total of 200 seedlings per treatment. Statistical differences between $\mathrm{Cu}$ concentrations and the control were evaluated using an analysis of variance (one-way or factorial ANOVA (analysis of variance) (quantification of photosynthetic pigments, and enzyme activity), applying Fisher's LSD multiple comparison test with the STATISTICA software (v 6.0). The graphics were prepared using the mean $\pm \mathrm{SE}$ with Microsoft Excel 2010 software (v14.0.7116.500). The differences between treatments were considered significant if $p<0.05$. 


\section{Results}

\subsection{Morpho-physiological variables}

According to the ANOVA, no effect of assay time was observed (30 and 60 days) on the analyzed variables; therefore, only the $\mathrm{CuSO}_{4} 5 \mathrm{H}_{2} \mathrm{O}$ concentration factor was considered to evaluate the significance of the effect of this on the studied parameters (Table 1). The presence of $\mathrm{Cu}$ (II) ions in the culture medium only significantly affected the number of shoots when the concentration was $500 \mu \mathrm{M}$, both with respect to the control $(0 \mu \mathrm{M})$ and the lower concentration
$(100 \mu \mathrm{M})$, observing a decrease in the number of new shoots. The number of roots showed a significant decrease in the presence of both $\mathrm{Cu}$ (II) ion concentrations in comparison with the control, without observing differences between the analyzed concentrations. Only the lowest concentration of $\mathrm{Cu}$ (II) ions significantly boosted the development of floral apices. Although the induction of floral apices was also observed in the presence of the highest ion concentration, this did not show significant differences with respect to the control. The studied concentrations showed no significant effect on the appearance of chlorosis symptoms in leaves and stems (Table 1).

Table 1. Quantitative variables in Colobanthus quitensis seedlings subjected to three $\mathrm{CuSO}_{4}$ concentrations for 60 days. Mean and SE $(\mathrm{n}=20)$. Differences between treatments $(*)$ were considered significant if $p<0.05$.

\begin{tabular}{llccc}
\hline Variable & Concentration (I) & Concentration (J) & $\begin{array}{l}\text { Mean difference } \\
(\mathrm{I}-\mathrm{J})\end{array}$ & SE \\
\hline Shoots (\%) & Control & $100 \mu \mathrm{M}$ & 5.0 & 9.35 \\
& & $500 \mu \mathrm{M}$ & $27.5^{*}$ & 9.35 \\
& $100 \mu \mathrm{M}$ & $500 \mu \mathrm{M}$ & $22.5^{*}$ & 9.35 \\
Roots (\%) & Control & $100 \mu \mathrm{M}$ & $60.0^{*}$ & 12.91 \\
& & $500 \mu \mathrm{M}$ & $80.0^{*}$ & 12.91 \\
& $100 \mu \mathrm{M}$ & $500 \mu \mathrm{M}$ & 20.0 & 12.91 \\
Floral apex (\%) & Control & $100 \mu \mathrm{M}$ & $-20.0^{*}$ & 8.42 \\
& & $500 \mu \mathrm{M}$ & -7.5 & 8.42 \\
& $100 \mu \mathrm{M}$ & $500 \mu \mathrm{M}$ & 12.5 & 8.42 \\
Chlorosis (\%) & Control & $100 \mu \mathrm{M}$ & -37.5 & 16.79 \\
& & $500 \mu \mathrm{M}$ & -37.5 & 16.79 \\
& $100 \mu \mathrm{M}$ & $500 \mu \mathrm{M}$ & 0.0 & 16.79 \\
\hline
\end{tabular}

Of the morphophysiological variables evaluated at the end of the study, only leaf length (Figure 1A) and root length (Figure 1B) showed significant differences in comparison to the control, with a decrease in both variables. Furthermore, although the trend was that this decline was directly associated with the increase in ion concentration, significant differences were not observed between the studied concentrations $(100 \mu \mathrm{M}$ and $500 \mu \mathrm{M})$. The variables, fresh weight, dry weight, water content, and Fv/Fm showed no significant differences in any of the evaluated treatments (data not shown). 

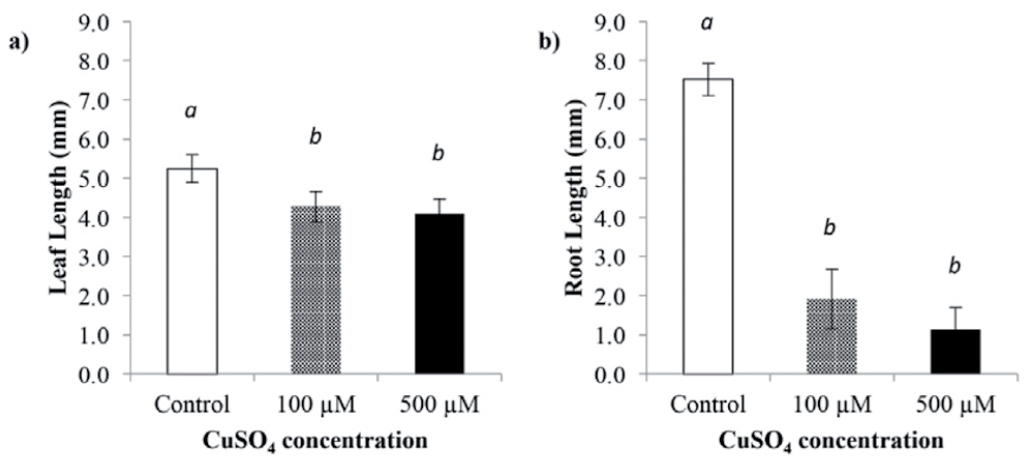

Figure 1. Leaf and root length of Colobanthus quitensis subjected to $\mathrm{CuSO}_{4}$ for 60 days. (a) Leaf Length, (b) Root Length. Mean \pm SE ( $\mathrm{n}=20$ ). Differences between treatments were considered significant if $p<0.05$.

\subsection{Biochemical variables}

A significant increase was observed in proline content in the plants subjected to the higher concentration of $\mathrm{Cu}$ (II) ions (48.23 $\mu \mathrm{g} \mathrm{mg}^{-1}$ fresh weight). The proline content between the control and the lower $\mathrm{Cu}$ concentration presented very similar values, 25.68 and 27.08 $\mu \mathrm{g} \mathrm{mg}^{-1}$ fresh weight, respectively (Figure 2A).

Regardless of the fact that the observed trend showed a decrease in pigment content (chlorophyll a, chlorophyll $\mathrm{b}$, and carotenoids) that was directly related to the increase in $\mathrm{Cu}$ (II) ions, significant differences were only observed in chlorophyll a content in the plants that were subjected to the highest $\mathrm{Cu}$ concentration $(500 \mu \mathrm{M})$ (Figure 2B).
MDA content was significantly greater in the plants that were in the presence of the highest $\mathrm{Cu}$ concentration (4364.52 $\mathrm{nmol} \mathrm{g}^{-1}$ ), while no differences were observed between the control and the lower concentration of $\mathrm{Cu}$ (II) ions (Figure 2C). Catalase activity (CAT) showed no significant differences for any of the performed treatments, although not the G-POD enzyme, whose activity was not detected in the control treatment, showed a significant increase in in presence of both $\mathrm{Cu}$ (II) ion concentrations (Figure 2 D). 

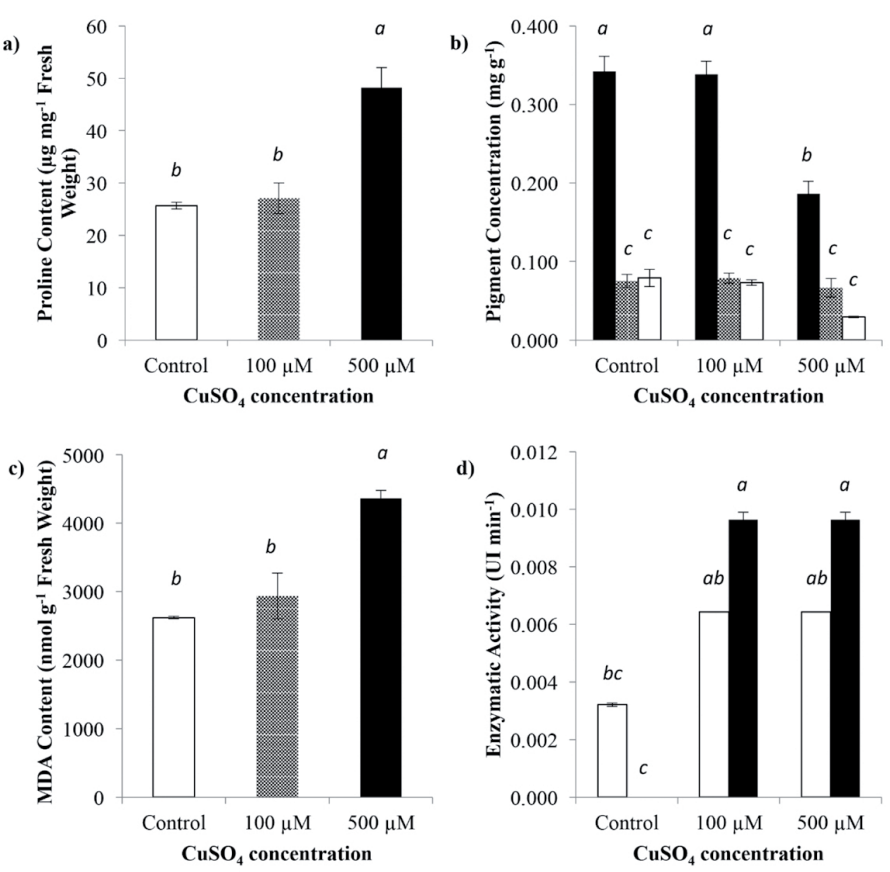

Figure 2. Biochemical variables of Colobanthus quitensis seedlings subjected to $\mathrm{CuSO}_{4}$ for 60 days. (a) Proline Content, (b) Photosynthetic Pigments (Black, Chl a; Grey, Chl b; White, Carotenoids), (c) Malondialdehyde (MDA) Content, (d) Enzymatic Activity (White, Catalasa (CAT); Black, Guaiacol peroxidase (G-POD)). Mean \pm $\mathrm{SE}(\mathrm{n}=3)$. Differences between treatments were considered significant if $p<0.05$.

\section{Discussion}

This is the first study to report on the effect of $\mathrm{Cu}$ ions in C. quitensis, allowing us to obtain new information on tolerance mechanisms that this species has developed to survive in extreme abiotic conditions, such as in the presence of metal ions which high concentrations can be toxic to most plants. According to our results, only high $\mathrm{Cu}$ concentration $(500 \mu \mathrm{M})$ exhibited a decrease in the number of new shoots, thus affecting plant growth and development. On the other hand, the effect on root system development was significantly harmful from the lowest concentration studied $(100 \mu \mathrm{M})$. This could indicate that C. quitensis showed greater sensitivity to the $\mathrm{Cu}$ ions in its root system. According to Marschner (2011) the effect of $\mathrm{Cu}$ toxicity is mainly observed in root tissues with a slight translocation towards the shoots. Some plants develop mechanisms such as the reorganization of root architecture in order to adapt to changes in the nutrient availability whether in excess or by default (López-Bucio et al., 2003). In the highest $\mathrm{Cu}$ (II) ion concentration, the root development of C. quitensis was practically non-existent, however, the plants were able to develop new shoots, although with a significant decrease regarding the lower concentration. This would indicate that, despite of the toxicity in root cells, the plant must have developed some strategy 
to continue its growth. Similar effects have been observed in other species such as Hordeum vulgare L. (Žaltauskaitè and Šliumpaitè, 2013), Brassica juncea L., and B. napus L. (Feigl et al., 2013).

In the presence of the lowest $\mathrm{Cu}$ concentration, the development of floral apices was evidenced in the first 30 days of the study. This factor has been considered a sign of adaptation in ecotypes that are tolerant to contaminated environments (McNeilly and Antonovics, 1968). Nonetheless, in in vitro studies, such as in this case, it is a variable that should be considered with discretion since it is related more to stress than with the events of plant development themselves (Cuba-Díaz et al., 2014).

According to Marschner (2011), the first symptoms of an initial $\mathrm{Cu}$ toxicity process are expressed in growth impairment and root elongation, which supports the absence of significant differences in physiological variables (dry weight, water content, and Fv/ $\mathrm{Fm}$ ); these indirectly indicate the proper functioning of photosynthesis. C. quitensis exhibited decreases in leaf and root growth that were directly related to the increase in $\mathrm{Cu}$ (II) ion concentration. Control plants exhibited differences in comparison to those that were treated with two $\mathrm{Cu}$ (II) ion concentration. On the other hand, both concentrations (100 and 500 $\mu \mathrm{M}$ ) showed a statistically identical behavior, regarding these two variables. This may provide insight on the species' tolerance range, which, moreover, continued to grow despite the decrease in its root system development. In other species such as Medicago sativa L (Flores-Cáceres et al., 2015) it has been highlighted that the increase in $\mathrm{Cu}$ concentration in the substratum negatively affects plant development, being more significant in root development. Other studies, such as in Hordeum vulgare L. (Žaltauskaitė and Šliumpaite, 2013) have been shown that $\mathrm{Cu}$ not only inhibits root system development, but also significantly decreases root length.
The amino acid proline is one of the main indicators to assess early metabolic responses to stress (Viehweger, 2014), being deemed a cell osmoprotector. In C. quitensis, the proline content only increased significantly in plants exposed to the higher $\mathrm{Cu}$ concentration. It has been observed that, in species with ecotypes tolerant and sensitive to metal, like Silene vulgaris G., the proline content in the presence of $\mathrm{Cu}$ was higher in the first (Schat et al., 1997). One of main protective function of proline is the antioxidant defense that would act through the reduction of ROS, mitigating the damage caused by metals (Viehweger, 2014). In addition, proline provides protection through $\mathrm{Cu}$ chelation in the cytoplasm, reduction in metal absorption, and plant osmoregulation, since the excess of this micronutrient collaterally generates an inhibition in water transportation, as well as a change in cell membrane permeability (Hayat et al., 2012). Protection to the water deficit could be confirmed in this study through the positive relationship between the presence of the proline and the water content in plants exposed to 500 $\mu \mathrm{M}$ (data not shown), since these did not express significant differences in water content with regard to the control seedlings.

Membrane fatty acid peroxidation is an indicator of oxidative damage in plants, therefore, is a biomarker of oxidative stress (Žaltauskaite and Šliumpaitè, 2013). This membrane damage, along with the enzyme inactivation, may occur due to the oxidative stress in the cell in the presence of excess metal ions (Thounaojam et al., 2012). In C. quitensis, only the $500 \mu \mathrm{M}$ concentration cause a significant increase in the malondialdehyde content (MDA), which may be indicative of certain peroxidative damage to the membrane. Lipid peroxidation is described as an extensive degradation factor of intracellular and organelle membranes, particularly in chloroplasts. Although $\mathrm{Cu}$ is an essential micronutrient for the plant's metabolism, lipid peroxidation and the destruction of the membranes 
caused by the excess of $\mathrm{Cu}$ can lead to chlorosis, an indicator of toxicity (Žaltauskaite and Šliumpaite, 2013). Although no significant difference was directly observed in plants color (chlorosis) between treatments (Table 1), a decrease was noted in chlorophyll a in the seedlings that were exposed to the higher $\mathrm{Cu}$ concentration for 60 days (Figure 2B). High concentration of copper has caused a decrease in chlorophyll a in others species such as tobacco (Khairy et al., 2016) and Brassica juncea L. (Singh et al., 2011), which has been associated with both destruction of chloroplast membranes and inhibition of aminolevulinate dehydratase (Scarponi and Perucci, 1984).

Catalase (CAT) and peroxidase (POD) are among the main enzymes which constitute the enzyme system catabolizing free radicals and $\mathrm{H}_{2} \mathrm{O}_{2}$ in plant cells. The activity of these enzymes generally increases in the plants, after the exposure to high concentrations of metals (Gill and Tuteja, 2010). In C. quitensis, the CAT did not show significant differences in any of the applied treatments. In contrast, the G-POD had significantly higher activity in the presence of the two $\mathrm{Cu}$ (II) ion concentrations evaluated. There is no information available in the literature on the activity of this enzyme in the species; however, in a similar study, where different sodium chloride concentrations were applied to in vitro C. quitensis plants, G-POD activity was not detected in control plants either (Castel, 2015). Thus, in this case, CAT would not be involved in an eventual defensive response to these $\mathrm{Cu}$ (II) concentrations. In glycine max L., the application of different arsenic concentrations decreased CAT activity but increased G-POD activity; the latter was associated with a higher participation in antioxidant responses to stress from toxic metal ions (Chandrakar, et al. 2016). Although the trend to activity increase observed in both enzymes analyzed in C. quitensis is similar to what is described by Singh et al. (2011) in Brassica juncea L., it differs considerably from the values reported in those studies, observing for $C$. quitensis that both enzymes show very low activity values.

\section{Conclusions}

High $\mathrm{Cu}$ concentrations $(500 \mu \mathrm{M})$ applied in in vitro culture on $C$. quitensis seedlings caused a decrease in seedling growth, mainly affecting root development. Other symptoms that may be stress indicators such as an increase in proline content, a decrease in photosynthetic pigments (chlorophyll a), increased oxidative damage to the membrane and to the activity of enzymes related to ROS detoxification also showed significant values regarding the control plants. However, after 60 days, the plants were still growing and did not show symptoms such as chlorosis, decreases in their photosynthetic activity, or a significant decrease in fresh weight and water content with respect to the control plants. Although these results are not sufficient, we can preliminarily propose that, regardless of showing certain symptoms of stress, C. quitensis is capable of generating a mechanism that allows it to tolerate the presence of toxic metal ion concentrations, even in the presence of high $\mathrm{Cu}$ concentrations.

\section{Acknowledgements}

This research was funded by the Vicerrectoría de Investigación y Desarrollo at the Universidad of Concepción (Grant: VRID 213.418.004-1.0). The authors would like to thank International Journal Revisions (journalrevisions.com) for the translation and final editing of this study as well as the reviewers, including Katarzyna Chwedorzewska, whose exhaustive work helped to improve the quality of our paper. 


\section{References}

Androsiuk P., Chwedorzewska K.J. Szandar K., Giełwanowska I. 2015. Genetic variation of the Colobanthus quitensis from King George Island (Antarctica). Polish Polar Research. 36, 281-295.

Bascuñán-Godoy, L., Sanhueza, C., Cuba-Díaz, M., Zúñiga, G.E., Corcuera, L.J., Bravo, L.A. 2012. Cold acclimation limits low temperature induced photoinhibition by promoting a higher photochemical quantum yield and a more effective PSII restoration in darkness in the Antarctic rather than the Andean ecotype of Colobanthus quitensis Kunth Bartl (Cariophyllaceae). BMC Plant Biology. 12, 114.

Bates, L.S., Waldren, R.P., Teare, I.D. 1973. Rapid determination of proline for water stress studies. Plant Soil. 39, 205-207.

Borsdorf, A., Dávila, C., Hoffert, H., Tinoco, C.L. 2012. Desde la Tierra del Fuego hasta el Caribe. Retrieved June 3rd, 2015 from: http://www. lateinamerika-studien.at/content/natur/naturesp/ natur-243.html.

Bravo, L.A., Saavedra-Mella, F.A., Vera, F., Guerra, A., Cavieres, L.A., Ivanov, A.L., Huner, N.P., Corcuera, L.J. 2007. Effect of cold acclimation on the photosynthetic performance of two ecotypes of Colobanthus quitensis (Kunth) Bartl. Journal of Experimental Botany. 58, 3581-3590.

Castel, K. 2015 Evaluación de tolerancia a la salinidad $(\mathrm{NaCl})$ de tres poblaciones de Colobanthus quitensis in vitro". [Tesis de Pregrado. Ing. Biotecnología Vegetal]. Universidad de Concepción, Chile 70 pp.

Chandrakar,V., Dubey, A., Keshavkant, S. 2016. Modulation of antioxidant enzymes by salicylic acid in arsenic exposed Glycine max L. Journal of Soil Science and Plant Nutrition. 16, 662-676.
Cheng, T., Rivard, B., Sánchez-Azofeifa, A.G., Féret, J.B., Jacquemoud, S., Ustin, S.L. 2012. Predicting leaf gravimetric water content from foliar reflectance across a range of plant species using continuous wavelet analysis. Journal Plant Physiology. $169,1134-1142$.

Cuba-Díaz, M., Acuña, D., Cordero, C., Klagges, M. 2014. Optimización de parámetros para la propagación in vitro de Colobanthus quitensis (Kunth) Bartl. Gayana Botánica. 71, 49-58.

Cuba-Díaz, M., Castel, K., Acuña, D., Machuca, A., Cid, I. 2017. Sodium chloride effect on Colobanthus quitensis seedling survival and in vitro propagation. Antarctic Science. 29, 45-46.

Dal Corso, G., Manara, A., Furini, A. 2013. An overview of heavy metal challenge in plants: from roots to shoots. Metallomics. 5, 117-321.

Dey, S., Mazumder, P.B., Paul, S.B. 2014. Effect of Copper on Growth and Chlorophyll Content in Tea Plants (Camellia Sinensis (L.) O. Kuntze). International Journal of Research in Applied, Natural and Social Sciences. 2, 223-230.

Dhindsa, R., Plump-Dhindsa, P., Thorpe, T. 1981. Leaf senescence: Correlated with increased levels of membrane permeability and lipid peroxidation, and decreased levels of superoxide dismutase and catalase. Journal of Experimental Botany 32, 93-101.

Feigl, G., Kumar, D., Lehotai, N., Tugyi, N., Molnár, Á., Ördög, A., Szepesi, Á., Gémes, K., Laskay, G., Erdei, L., Kolbert, Z. 2013. Physiological and morphological responses of the root system of Indian mustard (Brassica juncea L. Czern.) and rapeseed (Brassica napus L.) to copper stress. Ecotoxicology and Environmental Safety. 94, 179-189.

Flores-Cáceres, M., Hattab, S., Hattab, S., Boussetta, H., Banni, M., Hernández, L. 2015. Specific mechanisms of tolerance to copper and cadmium are compromised by a limited concentration of glutathione in alfalfa plants. Plant Science. 233, 165-173. 
Gill, S.S., Tuteja, N. 2010. Reactive oxygen species and antioxidant machinery in abiotic stress tolerance in crop plants. Plant Physiology and Biochemistry. 48, 909-930.

Hayat, S., Hayat, Q., Alyemeni, M., Wani, A., Pichtel, J., Ahmad, A. 2012. Role of proline under changing environments. Plant signaling \& Behavior. 7, 1456-1466.

Joshi, D, Srivastava, P.C., Dwivedi, R., Pachauri, S.P., Shukla A.K. 2015. Chemical speciation and suitablity of soil extractants for assessing $\mathrm{Cu}$ availability to maize (Zea mays L.) in acidic soils. Journal of Soil Science and Plant Nutrition. 15, 1024-1034.

Khairy, A., Oh, M., Lee, S., Kim, D., Roh, K. 2016. Nitric oxide overcomes $\mathrm{Cd}$ and $\mathrm{Cu}$ toxicity in in vitro grown tobacco plants through increasing contents and activities of rubisco and rubisco activase. Biochimie Open. 2, 41-51.

Kireyko, A.V., Veselova, I.A., Shekhovtsova, T.N. 2006. Mechanisms of peroxidase oxidation of odianisidine, 3,39,5,59-tetramethylbenzidine, and o-phenylenediamine in the presence of sodium dodecyl sulfate. Russian Journal of Bioorganic Chemistry. 32, 71-77.

Lewis-Smith, R.I. 1993. Dry costal ecosystems of Antarctica. In Maael E. van der (Eds.) Ecosystems of the world, 2A; Dry coastal ecosystems, polar regions and Europe. Elsevier, Amsterdam. pp 51-57.

Lewis-Smith, R.I. 2003. The enigma of Colobantus quitensis and Deschampsia antarctica in Antarctica. In: Huiskes, A.H.L., Gieskes, W.W.C., Rozema, J., Schorno, R.M.L., Van Der Vies, S.M., Wolff, W.J. (Eds.) Antarctic Biology in a Global Context (pp 234-239). Blackhuys, Leiden, the Netherlands.

López-Bucio, J., Cruz-Ramírez, A., Herrera-Estrella, L. 2003. The role of nutrient availability in regulating root architecture. Current Opinion Plant Biology. 6, 280-287.
Lu, Z., Cai, M., Wang, J., Yang, H. He, J. 2012. Baseline values for metals in soils on Fildes Peninsula, King George Island, Antarctica: the extent of anthropogenic pollution. Environmantal Monitoring and Assessment. 184, 7013-7021.

Marschner, H. 2011. Marschner's Mineral Nutrition of Higher Plants. Academic Press. 3ed: 672 pp.

McNeilly, T., Antonovics, J. 1968. Evolution in closely adjacent plant populations. Heredity. 23, 205218.

Moore, D. 1970. Studies in Colobanthus quitensis (Kunth) Bartl. And Deschampsia Antarctica Desv.: II.Taxonomy, distribution and relationships. British Antartic Survey Bulletin. 23, 63-80.

Scarponi, L., Perucci, P. 1984. Effect of some metals and related metal-organic compounds on ALA-dehydratase activity of corn. Plant and Soil. 79, 69-75.

Schat, H., Sharma, S.S., Vooijs, R. 1997. Heavy metal-induced accumulation of free proline in a metal-tolerant and a non-tolerant ecotype of Silene vulgaris. Physiologia Plantarum. 101, 477-482.

Sharma, P., Jha, A.B., Dubey, R.S., Pessarakli, M. 2012. Reactive oxygen species, oxidative damage, and antioxidative defense mechanism in plants under stressful conditions. Journal of Botany. Article ID 217037, 26 pages. doi:10.1155/2012/217037.

Singh, S., Singh, S.H., Ramachandran, V., Eapen, S. 2011. Copper tolerance and response of antioxidative enzymes in axenically grown Brassica juncea (L.) plants. Ecotoxicology and Environmental Safety. 73, 1975-1981.

Sreekanth, T.V.M., Nagajyoti, P.C., Lee, K.D., Prasad, T.N.V.K.V. 2013. Occurrence, physiological responses and toxicity of nickel in plants. International Journal of Environmental Science and Technology 10, 1129-1140.

Steubing, L., Godoy, R., Alberdi, M. 2002. Métodos de ecología vegetal Editorial Universitaria, Santiago, Chile. pp 345. 
Thounaojam, T., Panda, P., Mazumdar, P., Kumar, D., Sharma, G., Sahoo, L., Sanjib, P. 2012. Excess copper induced oxidative stress and response of antioxidants in rice. Plant physiology and biochemistry 53, 33-29.

Ulrich, B.H. 1974. Catalase. Methods of Enzymatic Analysis. New York: Academic Press, Inc pp: 673-684.

Verdejo, J., Ginocchio, R., Sauvé, S., Mondaca, P., Neaman, A. 2016. Thresholds of copper toxicity to lettuce in field-collected agricultural soils exposed to copper mining activities in Chile. Journal of Soil Science and Plant Nutrition. 16,154-158. Viehweger, K. 2014. How plants cope with heavy metals. Botanical Studies. 55, 1-12.
Violante, A., Cozzolino, V., Perelomov, L., Caporale, A.G., Pigna, M. 2010. Mobility and bioavailability of heavy metals and metalloids in soil environments. Journal of Soil Science and Plant Nutrition. 10, 268-292.

Wuana, R.A., Okieimen, F.E. 2011. Heavy metals in contaminated soils: a review of sources, chemistry, risks and best available strategies for remediation. ISRN Ecology. Article ID 402647. 20 pages. http://dx.doi.org/10.5402/2011/402647

Žaltauskaitè, J., Šliumpaitè, I. 2013. Single and combined toxicity of copper and cadmium to $\mathrm{H}$. vulgare growth and heavy metal bioaccumulation. E3S Web of Conferences. 1, 15013p1-15013p4. 